\title{
Analysis of The Entrepreneurial Intention's Emergence at Business and non-Business Students in Indonesia
}

\author{
Eriana Astuty*, Okky Rizkia Yustian \\ Entrepreneurship Department, Bina Nusantara University, Indonesia \\ *Corresponding e-mail: eriana.astuty@binus.ac.id
}

Received: 17 February 2021

Accepted: 05 March 2021

Published: 21 March 2021

Abstract: Analysis of The Entrepreneurial Intention's Emergence at Business and nonBusiness Students in Indonesia. Objective: This study confirm empirically the student entrepreneurial intentions (SEI) related to the study program, family background, students' business experience; and describing the reflection of the SEI at several universities in Indonesia. Method: A survey-type quantitative approach, using descriptive, contingency, and CFA analysis. Findings: The Study programs have a relationship with the emergence of SEI. In addition, the family background in doing business and the student's business experience did not show a relationship with SEI in business students, but against non-business students. Conclusion: Not only business study programs capable of arousing SEI, but non-business study programs can also trigger SEI, even though non-business study programs do not provide entrepreneurship learning as much as the business study program curriculum. This finding is interesting to discuss because it can explore what kind of business or non-business study programs can actually strengthen the SEI.

Keywords: entrepreneurial intention, family background, business experience, study program, curriculum Abstrak: Analisis Munculnya Niat Wirausaha pada Mahasiswa Program Studi Bisnis dan Non Bisnis di Indonesia. Tujuan: Mengkonfirmasi secara empiris niat berwirausaha mahasiswa (Student Entrepreneurial Intention/SEI) dikaitkan dengan program studi, latar belakang keluarga, pengalaman bisnis mahasiswa; serta mendeskripsikan cerminan SEI di beberapa perguruan tinggi di Indonesia. Metode: Pendekatan kuantitatif berjenis survei, dengan menggunakan analisis deskriptif, kontingensi, dan CFA. Temuan: Prodi memiliki hubungan terhadap munculnya SEI. Selanjutnya, latar belakang keluarga yang berbisnis, serta pengalaman berbisnis tidak berhubungan dengan SEI pada mahasiswa prodi bisnis, hal ini bertentangan dengan mahasiswa prodi non-bisnis. Kesimpulan: Tidak hanya prodi bisnis saja yang mampu membangkitkan SEI, tetapi prodi non-bisnis juga dapat memicu munculnya SEI tidak menyediakan pembelajaran kewirausahaan sebanyak kurikulum prodi bisnis. Temuan ini menjadi menarik untuk didiskusikan karena dapat menggali prodi yang bagaimana yang dapat memperkuat munculya niat berwirausaha mahasiswa.

Kata kunci: niat berwirausaha, latar belakang keluarga pebisnis, pengalaman berbisnis mahasiswa, program studi, kurikulum

\section{To cite this article:}

Astuty, E. \& Yustian, O. R. (2021). Analysis of The Entrepreneurial Intention's Emergence at Business and non-Business Students in Indonesia. Jurnal Pendidikan Progresif, 11(1), 27-38. doi: 10.23960/ jpp.v11.i1.202103 


\section{INTRODUCTION}

The emergence of entrepreneurial intentions among students is one of the important goals of effective entrepreneurship learning (Lavelle, 2019; Nabi, Linan, Fayolle, Krueger, \& Walmsley, 2017; Shneor, Smith, Smith, \& Michael Goedecke, 2020) because it can trigger business creation activities (Kourilsky \& Walstad, 1998; Sancho, Martín-Navarro, \& Antonio Rafael Ramos-Rodríguez, 2020). There are many stimuli in generating entrepreneurial intentions among students, including the influence of family members as businessmen (Carr \& Sequeira, 2007; Chlosta, Patzelt, Klein, \& Dormann, 2012; Shirokova, Osiyevskyy, \& Bogatyreva, 2016); working experience (Kautonen, Luoto, \& Tornikoski, 2010) which states that working experience for young people tends to be more towards entrepreneurial activities than senior age, and this is confirmed to be one of the predictors of entrepreneurship; entrepreneurship learning through formal entrepreneurship education they get in college (Lackéus, 2020; Lavelle, 2019; Paray \& Kumar, 2020; Shirokova et al., 2016); curriculum and lecturer-competency (Iwu et al., 2019; Nielsen \& Stovang, 2015); individual-level of entrepreneurial orientation (Martins \& Perez, 2020). Moreover, entrepreneurship education which is equipped with effective entrepreneurship training will be able to improve student entrepreneurial skills (Gieure, BenavidesEspinosa, \& Roig-Dobón, 2019) which in turn can increase the likelihood of students starting a business. Meanwhile, other researchers found the opposite where entrepreneurship education was only able to increase student self-efficacy in Norway, but not student entrepreneurial attitudes and intentions. (Shneor et al., 2020).

Research related to entrepreneurship in tertiary institutions is growing and increasingly being studied by academics and policy makers, it is even confirmed that entrepreneurship learning today does not only belong to the curriculum for business studies, but is important and relevant to be developed in non-business study programs because entrepreneurship is a complex set of qualities, beliefs, attitudes and skills that underpin all areas of work life (Bridgstock, 2013). The process of structuring entrepreneurship learning into an interdisciplinary curriculum structure must be designed to be relevant to the career context (Bridgstock, 2013) and scientific context (Lindahl Thomassen, Williams Middleton, Breum Ramsgaard, Neergaard, \& Warren, 2019) because entrepreneurship learning is not "ceteris paribus" (Lindahl Thomassen et al., 2019), This is in line with the finding that entrepreneurship is a dynamic academic field with a rich history (Gupta et al., 2016). Another researcher confirmed that educative entrepreneurial experiences in the entrepreneurship learning process aim to make students can learn entrepreneurship through education. It's a comprehensive method, consists of the student entrepreneurs' journey and the educational context (Hägg \& Kurczewska, 2019), this method is intended so that students can learn entrepreneurship through education. Entrepreneurial intention which is an important issue in this study can be measured by several manifestation variables, including through student personality variables such as awareness, openness, emotional stability, friendliness, and self-efficacy. (Pahin, Karadað, \& Tuncer, 2019). In addition, other researchers have found other manifestations, namely career priority, preferred career, seriousness, determination, and readiness (Bazan et al., 2019).

Based on the literature review on the research background above, the researcher found a research gap in the form of unconsistency towards the findings related to students' entrepreneurial intentions and their antecedents, so the researchers formulated several research questions in this study, namely (1) Is there a linkage (relationship) between business and non- 
business study programs; businessman family background; student's business experience on the emergence of entrepreneurial intentions? (2) What is the reflection of Indonesian students who have entrepreneurial intentions?. The research questions above lead the researcher to prove empirically on the designed research subject, so this study aims to confirm empirically the emergence of student entrepreneurial intentions associated with the study program taken (business or non-business); associated with the background of the businessman family; associated with students' business experience; as well as confirming the factors that reflect the entrepreneurial intention of each student at several universities in Indonesia.

\section{METHOD}

\section{Reearch Design and Procedure}

This research uses a survey-type quantitative approach with the object of study in the form of student entrepreneurial intentions, entrepreneurial family backgrounds, student entrepreneurial experience backgrounds, and the study program (majors) that students undertake on campus. Researchers conducted the research in 6 months, from August 2020 to January 2021. Locations of research are seven public universities and eleven private universities in Java and Sumatera.

This research will be carried out in several stages as follows: (1) Testing the validity and reliability of the data generated in the pre-survey to test the instruments used: (2) Empirical evidence through contingency testing related to the emergence of student entrepreneurial intentions with several antecedents such as study programs taken by students, the existence of family members who become entrepreneurs, as well as business experience from students; (3) Testing the measurement model on the student entrepreneurial intention variable in order to analyze the reflection arising from the student's entrepreneurial intention through confirmatory factor analysis.

The measurement of the student entrepreneurial intention variable in this study will adopt the findings of Bazan et. al (2019) which uses 5 indicators, namely career priority, preferred career, seriousness, determination, and readiness (Bazan et al., 2019), and then be used in confirmatory factor analysis in order to prove the existence of entrepreneurial intentions that have emerged in students at several universities in Indonesia.

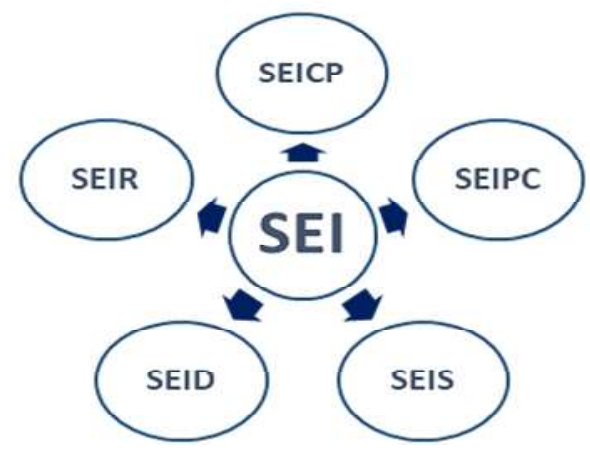

Note:

$\mathrm{SEI}=$ Student Entrepreneurial Intention;

SEICP $=$ SEI-Career Priority;

SEIPC $=$ SEI-Preferred Career;

SEIS=SEI-Seriousness;

SEID $=$ SEI-Determination;

SEIR=SEI-Readiness;

Figure 1. Student Entrepreneurial Intentions Reflective Indicators (Bazan et. al., 2019)

\section{Sample Demographics}

The research subjects are universities in Indonesia with students as the unit of analysis. The following is the distribution of the surveyed Public Universities in Java and Sumatra randomly, namely: Institut Teknologi Bandung, Politeknik Negeri Bandung, Universitas Pendidikan Indonesia, Universitas Jember, Universitas Negeri Medan, Universitas Sriwijaya, Universitas Teuku Umar. In addition, researchers also 
conducted a survey to several private universities in Java and Sumatra randomly, including: Universitas Bina Nusantara Jakarta-BandungMalang, Universitas Telkom Bandung, Universitas Dinamika Bangsa Jambi, Islamic Fashion Institute, Bandung, Universitas Langlang Buana Bandung, Universitas Muhammadiyah Malang, Universitas Parahyangan Bandung, Politeknik Pos Indonesia Bandung, STIE INABA Bandung, STIMI Meulaboh Aceh, Universitas Widyatama Bandung.

Demographic data analyzed in this study include the number of universities surveyed as many as 18 universities consisting of 7 Public Universities (PTN) and 11 Private Universities (PTS); The number and age of students who participated in filling out the questionnaire, as well as the distribution of study programs currently occupied. Figure 1 presents the age distribution of respondents who participated in this study.

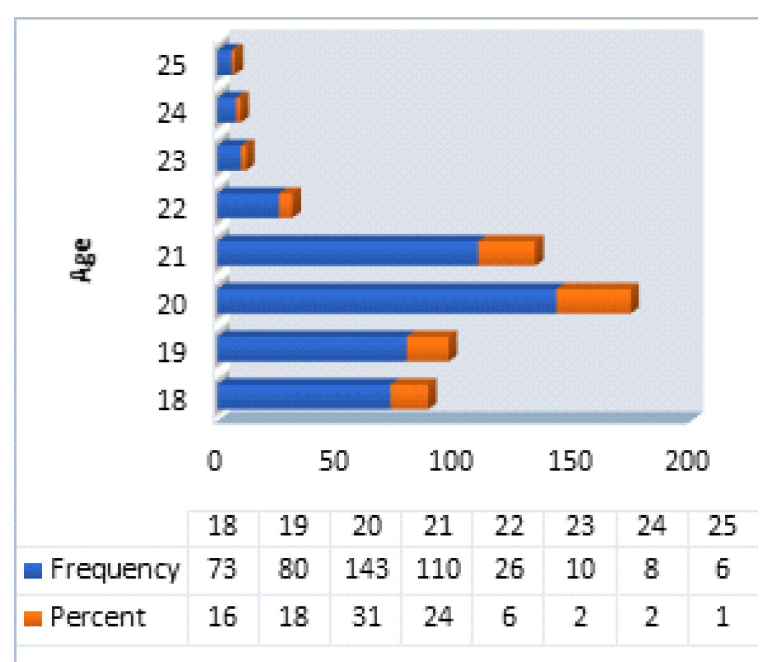

Figure 2. Respondent's Age

The minimum age of the respondents who participated in filling out the research instruments was 18 years and the maximum was 25 years. The mean of respondents was 20 years old, with a standard deviation of 1.47 years. Most respondents who participated in this study were students aged 20 years, followed by the next most were students aged 21 years. The random distribution of data to students of business and non-business study programs resulted in 456 data, consisting of $51 \%$ of respondents coming from business study program students and $49 \%$ of respondents from non-business study programs.

\section{Data, Instruments, Data Collecting}

The online questionnaire as an instrument in this research was distributed using a crosssectional survey for 3 months to the students from 7 Public Universities and 11 Private Universities in Java and Sumatra randomly. In an effort to obtain accurate and representative data related to the object of study, the authors do not limit its distribution to business study program students only, but also to non-business study programs.

Before conducting a thorough research, the researcher conducts a pre-survey first to test the instruments used in measuring the research variables to be observed. The validity of this research instrument was measured using the SPSS 20 by measuring the consistency of the correlation between the item score and the overall score on each research variable. The instrument is said to be valid if the level of significance as measured by the $p$-value is less than $<0.05$, and it will be said to be very valid if the resulting $p$ value is much smaller than á (Hair, Black, Babin, \& Anderson, 2014). Meanwhile, reliability is identified if the resulting reliability coefficient value is $>0.7$ (Hair et al., 2014). In this study, the value of the reliability coefficient was measured using the Cronbach's Alpha value on the SPSS20.

The results of instrument testing on 30 preliminary data showed that the research instruments used were valid and reliable so that the instruments could be forwarded and distributed randomly to all respondents from 7 Public Universities and 11 Private Universities in Java and Sumatra. The data that has been collected is 477 data, then filtered to avoid 
missing data, outlier data, and straight-line patterned data. The results of the filtering left 456 data which were declared suitable for further processing in this study.

\section{Data Analysis Technique}

Data analysis was performed using: (1) Descriptive analysis by exploring demographic data to determine the characteristics of respondents who participated in the study. The purpose of analyzing demographic data is to describe the characteristics of the unit of analysis related to the research object (Sekaran \& Bougie, 2016); (2) Contingency analysis using crosstab on SPSS 20 to determine the relationship between family background as a businessman, student entrepreneurial experience, and programs studies undertaken on the emergence of student entrepreneurial intentions. This analysis using a cross tabulation of two categorical variables which has the ability to convert nonmetric data to the metric level. This analysis is useful for providing a multivariate representation of interdependence for nonmetric data that is not possible with other methods (Hair, Black, Babin, \& Anderson, 2014); (3) Confirmatory factor analysis using AMOS 22 in order to obtain empirical evidence about what factors reflect the emergence of entrepreneurial intentions in students as a result of their association with several objects of study in this study. By using confirmatory factor analysis on the measurement model of a latent variable, researchers can test analytically the conceptual theory used by explaining how the items measured represent important psychological, sociological, or business measures. (Hair et al., 2014).

\section{RESULT AND DISCUSSION}

The respondents of this study were divided into business and non-business study programs students from 7 Public and 11 Private Universities in Java and Sumatra.

Table 1. Number of Respondent of Business and non-Business Study Program at PTN/PTS* surveyed

\begin{tabular}{lcr}
\hline \multicolumn{1}{c}{ Business Study Program } & Frequency & \% \\
\hline Creativepreneurship & 92 & 39.48 \\
Business Creation & 2 & 0.86 \\
Business Management & 33 & 14.16 \\
Telecommunication \& Informatics Business Mgt. & 24 & 10.30 \\
Entrepreneurship & 23 & 9.87 \\
Business Administration & 1 & 0.43 \\
Business Education & 54 & 23.18 \\
Business Logistics & 4 & 1.72 \\
\hline Total non-Business Study Program & $\mathbf{2 3 3}$ & $\mathbf{1 0 0}$ \\
\hline \multicolumn{1}{c}{ Frequency } \\
\hline Management & 46 & $\mathbf{\%}$ \\
International Marketing & 1 & 20.63 \\
Game Application \& Technology & 3 & 0.45 \\
Marketing Communication & 1 & 1.35 \\
Accounting & 59 & 0.45 \\
Informatics Engineering & 52 & 26.46 \\
Software Engineering & 4 & 23.32 \\
Planology Techniques & 1 & 1.79 \\
Biology & 1 & 0.45 \\
& & 0.45
\end{tabular}




\begin{tabular}{lcc} 
Civil Engineering & 2 & 0.90 \\
Civil Construction Engineering & 6 & 2.69 \\
Commercial Administration & 7 & 3.14 \\
Asset Management & 5 & 2.24 \\
Refrigeration Technique & 1 & 0.45 \\
Energy Conservation Engineering & 1 & 0.45 \\
Refrigeration \& Air Conditioning & 1 & 0.45 \\
Marketing & 2 & 0.90 \\
Electrical Engineering & 1 & 0.45 \\
Agrotechnology & 1 & 0.45 \\
Sociology & 1 & 0.45 \\
Economic Development Studies & 2 & 0.90 \\
Public Health Sciences & 1 & 0.45 \\
Computer System & 4 & 1.79 \\
Computer Network Engineering & 1 & 0.45 \\
Information Systems & 14 & 6.28 \\
Computer Science & 1 & 0.45 \\
Communication Studies & 2 & 0.90 \\
Fashion Design & 2 & 0.90 \\
\hline Total & $\mathbf{2 2 3}$ & $\mathbf{1 0 0}$ \\
\hline
\end{tabular}

*PTN = Public University; PTS = Private University

The total number of students who participated in this study was 456 students with a distribution of $51 \%$ (233 students) being business study program students and $49 \%(223$ students) being non-business study program students. The random distribution of online questionnaires to several university students in Java and Sumatra (both business and nonbusiness study program students) is intended so that the data obtained is able to produce accurate and representative empirical evidence in explaining the object of study in this study.

Referring to the results of cross tabulation between study program and student entrepreneurial intention in table 2 below, it can be seen that the p-value of the chi-square test is $0.001(<0.05)$. These results confirm the existence of a linkage (relationship) between the emergence of entrepreneurial intentions and the chosen study program in higher education.

Table 2. Result of Study Programs versus Student Entrepreneurial Intentions Cross-Tabulation

\begin{tabular}{|c|c|c|c|c|c|c|c|}
\hline & \multicolumn{6}{|c|}{ Student Entrepreneurial Intentions } \\
\hline & & VL & $\mathrm{L}$ & $\mathrm{M}$ & $\mathrm{H}$ & $\mathrm{VH}$ & $\mathrm{T}$ \\
\hline \multirow[t]{2}{*}{ Study Program } & business & 1 & 21 & 57 & 87 & 67 & 233 \\
\hline & non-business & 5 & 17 & 78 & 91 & 32 & 223 \\
\hline \multicolumn{2}{|l|}{ Total } & 6 & 38 & 135 & 178 & 99 & 456 \\
\hline \multicolumn{8}{|c|}{ Chi-Square Tests } \\
\hline \multirow{2}{*}{\multicolumn{2}{|c|}{ Pearson Chi-Square }} & \multirow{2}{*}{\multicolumn{2}{|c|}{ Value }} & & \multicolumn{3}{|c|}{ Asymp. Sig. (2-sided) } \\
\hline & & & $18.608^{a}$ & 4 & & & 1 (sig) \\
\hline
\end{tabular}

*VL=Very Low; L=Low; M=Moderate; $\mathrm{H}=$ High; $\mathrm{VH}=$ Very High; $\mathrm{T}=$ Total 
Which study program is effective in generating student entrepreneurial intentions? or what course content curriculum can lead to student entrepreneurial intentions? further research is needed to answer this question. As a literature review on this, previous researchers have obtained several findings, among others much research and effort has been done to increase opportunities for engineering students to develop an entrepreneurial mindset (Blake Hylton, Mikesell, Yoder, \& LeBlanc, 2020), In addition, it was found that study programs that are able to adapt entrepreneurship learning to local wisdom or regional attachments are proven to be able to publish student entrepreneurial intentions (Franco, Haase, \& Lautenschläger, 2010), the study program that provide the curriculum bridging current conditions with what might happen in the future together with students who collaborate with different stakeholders could increase the entrepreneurial intention (Nielsen \& Stovang, 2015), and all of that finding is very possible as input for university policymakers to reorient the curriculum (Brown, 2018). Another finding states that entrepreneurship learning through creative capacity building can increase student selfefficacy (Fleck \& Asmuth, 2020) which in the end was able to increase students' entrepreneurial intentions ('ahin et al., 2019).

Table 3. Cross-Tabulation Result of Family Background and Student Entrepreneurial Intention, using Study Program as Control Variable

\begin{tabular}{|c|c|c|c|c|c|c|c|c|}
\hline & \multirow{2}{*}{\multicolumn{2}{|c|}{ Study Programs }} & \multicolumn{5}{|c|}{ Student Entrepreneurial Intention } & \multirow[b]{2}{*}{ TOT } \\
\hline & & & VL & $\mathrm{L}$ & $\mathrm{M}$ & $\mathrm{H}$ & $\mathrm{VH}$ & \\
\hline \multirow{5}{*}{ 怘 } & \multirow{5}{*}{ 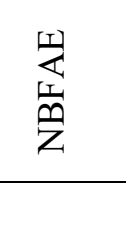 } & $0-2$ person & 0 & 12 & 32 & 52 & 36 & 132 \\
\hline & & 3-4 person & 1 & 7 & 18 & 20 & 20 & 66 \\
\hline & & 5-6 person & 0 & 2 & 6 & 11 & 9 & 28 \\
\hline & & $7-8$ person & 0 & 0 & 1 & 4 & 2 & 7 \\
\hline & & Total & 1 & 21 & 57 & 87 & 67 & 233 \\
\hline \multirow{6}{*}{ 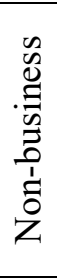 } & \multirow{6}{*}{$\begin{array}{l}\sum_{1}^{2} \\
\text { 空 } \\
\text { Z }\end{array}$} & 0-2 person & 4 & 11 & 55 & 73 & 18 & 161 \\
\hline & & 3-4 person & 1 & 5 & 19 & 7 & 6 & 38 \\
\hline & & 5-6 person & 0 & 0 & 4 & 8 & 5 & 17 \\
\hline & & $7-8$ person & 0 & 1 & 0 & 2 & 3 & 6 \\
\hline & & 9-10person & 0 & 0 & 0 & 1 & 0 & 1 \\
\hline & & Total & 5 & 17 & 78 & 91 & 32 & 223 \\
\hline \multirow{6}{*}{ 䒿 } & \multirow{6}{*}{ 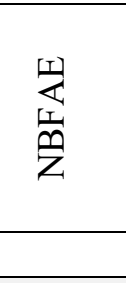 } & $0-2$ person & 4 & 23 & 87 & 125 & 54 & 293 \\
\hline & & $3-4$ person & 2 & 12 & 37 & 27 & 26 & 104 \\
\hline & & 5-6 person & 0 & 2 & 10 & 19 & 14 & 45 \\
\hline & & $7-8$ person & 0 & 1 & 1 & 6 & 5 & 13 \\
\hline & & 9-10person & 0 & 0 & 0 & 1 & 0 & 1 \\
\hline & & Total & 6 & 38 & 135 & 178 & 99 & 456 \\
\hline \multicolumn{8}{|c|}{ Chi-Square Tests } & \multirow[t]{2}{*}{$\mathrm{CC}$} \\
\hline \multicolumn{2}{|c|}{ Study Program } & \multicolumn{3}{|c|}{ Value } & $\mathrm{df}$ & \multicolumn{2}{|c|}{ Asymp. Sig. } & \\
\hline \multirow{3}{*}{\multicolumn{2}{|c|}{$\begin{array}{l}\text { Business } \\
\text { Non-Business } \\
\text { Total }\end{array}$}} & \multirow{3}{*}{$\begin{array}{l}\text { Pearson } \\
\text { Square }\end{array}$} & & $6.130^{\mathrm{b}}$ & 12 & \multicolumn{2}{|c|}{.909 (ns) } & .160 \\
\hline & & & & $5.757^{\mathrm{c}}$ & 16 & \multirow{2}{*}{\multicolumn{2}{|c|}{$\begin{array}{r}.048 \text { (sig) } \\
.207 \\
\end{array}$}} & .322 \\
\hline & & & & $0.309^{\mathrm{a}}$ & 16 & & & \\
\hline
\end{tabular}


Furthermore, referring to the results of cross tabulation between businessman family background and business intention using study program as control variable in Table 3 can be seen that the $\mathrm{p}$-value on the chi-square test is 0.909 for business study program students and 0.048 for non-business study program students. This means that the businessman family background in business study program students does not show a linkage (relationship) with the emergence of entrepreneurial intentions, this result is in line with the findings of previous researchers which state that there is no direct "family effect" on entrepreneurial intentions. (Franco et al., 2010), meanwhile, in nonbusiness study program students, the exposure to this family was sufficient, even though it was only $32.2 \%$, This is in line with the findings of previous researchers who state that there is a relationship between family business experience and entrepreneurial intentions (Carr \& Sequeira, 2007; Chlosta et al., 2012).

Table 4. Cross-Tabulation Result of Student Entrepreneurial Experience before Entering The College and Student Entrepreneurial Intention, using Study Program as Control Variable

\begin{tabular}{|c|c|c|c|c|c|c|c|c|}
\hline \multirow{2}{*}{\multicolumn{3}{|c|}{ Study Programs }} & \multicolumn{5}{|c|}{ Student Entrepreneurial Intention } & \multirow{2}{*}{ TOTAL } \\
\hline & & & VL & $\mathrm{L}$ & $\mathrm{M}$ & $\mathrm{H}$ & VH & \\
\hline \multirow{5}{*}{ 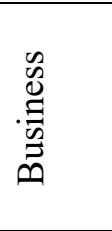 } & \multirow{4}{*}{ 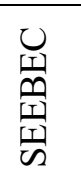 } & $\mathrm{N}$ & 1 & 4 & 15 & 18 & 12 & 50 \\
\hline & & JT & 0 & 16 & 32 & 46 & 36 & 130 \\
\hline & & $\mathrm{PN}$ & 0 & 1 & 8 & 20 & 17 & 46 \\
\hline & & FN & 0 & 0 & 2 & 3 & 2 & 7 \\
\hline & \multicolumn{2}{|r|}{ Total } & 1 & 21 & 57 & 87 & 67 & 233 \\
\hline \multirow{5}{*}{ 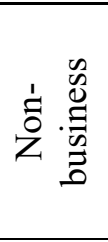 } & \multirow{5}{*}{ 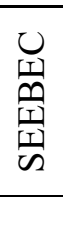 } & $\mathrm{N}$ & 2 & 11 & 23 & 24 & 5 & 65 \\
\hline & & JT & 1 & 5 & 42 & 41 & 10 & 99 \\
\hline & & $\mathrm{PN}$ & 0 & 1 & 10 & 25 & 14 & 50 \\
\hline & & $\mathrm{FN}$ & 2 & 0 & 3 & 1 & 3 & 9 \\
\hline & & Total & 5 & 17 & 78 & 91 & 32 & 223 \\
\hline \multirow{5}{*}{$\stackrel{\pi}{0}$} & \multirow{5}{*}{ 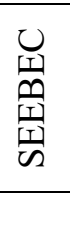 } & $\mathrm{N}$ & 3 & 15 & 38 & 42 & 17 & 115 \\
\hline & & JT & 1 & 21 & 74 & 87 & 46 & 229 \\
\hline & & $\mathrm{PN}$ & 0 & 2 & 18 & 45 & 31 & 96 \\
\hline & & $\mathrm{FN}$ & 2 & 0 & 5 & 4 & 5 & 16 \\
\hline & & Total & 6 & 38 & 135 & 178 & 99 & 456 \\
\hline \multicolumn{8}{|c|}{ Chi-Square Tests } & \\
\hline \multicolumn{5}{|c|}{ Study Programs } & Value & df & Asymp Sig. & \\
\hline \multirow{3}{*}{\multicolumn{3}{|c|}{$\begin{array}{l}\text { Business } \\
\text { Non-business } \\
\text { Total }\end{array}$}} & son Chi- & & $12.116^{\mathrm{b}}$ & 12 & $.436(\mathrm{~ns})$ & .222 \\
\hline & & & & & $49.033^{c}$ & 12 & .000 (sig) & .425 \\
\hline & & & & & $44.240^{\mathrm{a}}$ & 12 & .000 & \\
\hline
\end{tabular}

Referring to the cross tabulation between student entrepreneurial experience and business intention using study program as control variable, the p-value on the chi-square test in table 4 shows the results of 0.436 (not sig.) for business study program students and 0.000 for 
non-business study program students. This proves that there is no relationship between past business experiences that have been carried out by business study program students with the emergence of entrepreneurial intentions, while in non-business study program students it is confirmed that there is a relationship of $42.5 \%$ between their past business experiences with their intention to become entrepreneurs. The findings in non-business study program students are in line with the findings which state that work experience at a young age who tends to be entrepreneurial is confirmed as one of the predictors of entrepreneurship. (Kautonen et al., 2010).

Furthermore, the researcher will conduct a confirmatory factor analysis (CFA) for getting answers to the question "How is the reflection that comes from students who have entrepreneurial intentions?". To answer this, the researcher ran the SEI observation variable and all its indicators on the measurement model using the AMOS22 statistical data processor to produce the loading factor value, probability value, construct reliability, and variance extract, along with the goodness of fit values needed in the confirmatory factor analysis. The results of this CFA are presented in figure 3 .

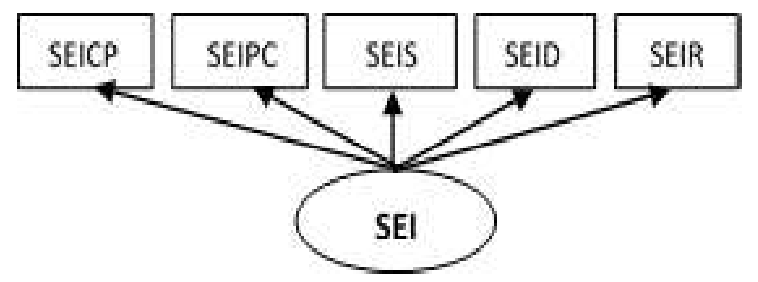

SEI $=$ Student Entrepreneurial Intention; $\mathrm{SEICP}=\mathrm{SEI}-\mathrm{Career}$ Priority; SEIPC $=$ SEIPreferred Career;

SEIS=SEI-Seriousness; SEID=SEI-Determination; SEIR=SEI-Readiness;

ChiSquare $=39.055 \mathrm{p}=.000 ; \mathrm{GFI}=.967 \mathrm{AGFI}=.901$ $\mathrm{CFI}=.980$

Figure 3. Confirmatory Factor Analysis of SEI
Figure 3 shows all loading factor values (ë) of the indicators $\mathrm{SEICP}=0.85, \mathrm{SEIPC}=0.84$, $\mathrm{SEIS}=0.75, \mathrm{SEID}=0.90, \mathrm{SEIR}=0.77$ (all of loading factors value e" $\mathrm{E}$

$\mathrm{L} \square>$

[0.5) and significant $(\mathrm{p}<0.05)$; Also obtained the value of Construct Reliability from the variable $\mathrm{SEI}=0.9$ and the value of Variance Extract $=0.7$, so that it can be stated that all indicators of the variable SEI are valid and reliable. In addition, $3 \mathrm{GOF}$ measures have met the fit criteria $(\mathrm{GFI}=0.967, \mathrm{AGFI}=0.901$, and $\mathrm{CFI}=0.980$ ) so that the SEI measurement model can be declared fit with empirical data in several universities in Java and Sumatra. This indicates the power of a good measurement model.

The CFA evidence above states that the following indicators are valid and reliable, proven to appear as a reflection of the entrepreneurial intention in students; among others: (1) SEICareer Priority, where being an entrepreneur is a student's top priority as a career choice after graduating from college; (2) SEI-Preferred Career, which shows that students prefer to be entrepreneurs rather than company employees; (3) SEI-Seriousness, which ch shows that students are very serious in thinking about the things that need to be done to start a business; (4) SEI-Determination, which shows the determination of students to become entrepreneurs; (5) SEI-Readiness, shows the readiness of students to do the things needed to become an entrepreneur. of students to become entrepreneurs.

Based on the results of the Confirmatory Factor Analysis on the SEI measurement model, it is empirically proven that the determination to become an entrepreneur (SEID) is the most dominant reflection of the emergence of the intention from students in several universities in Java and Sumatra to become entrepreneurs, but seriousness in thinking about the things that need to be done to start a business is the weakest 
indicator even though it is considered valid (loading factor $=0.75$ ).

\section{CONCLUSION}

The results of this study prove empirically that the study programs (majors) in 7 Public Universities and 11 Private Universities in Java and Sumatra have a relationship with the emergence of student entrepreneurial intentions. This means that not only business study programs are able to generate entrepreneurial intentions for students, but non-business study programs can trigger students' intention to become entrepreneurs. There are many previous studies that confirm some of the antecedents of entrepreneurial intention in business and nonbusiness study programs, among others: reorienting the entrepreneurship education curriculum in each study program that is contextual and relevant to scientific disciplines (Blake Hylton et al., 2020; Bridgstock, 2013; Brown, 2018; Lindahl Thomassen et al., 2019); study programs that present a curriculum that is relevant to learning patterns that maximize student creative capacity (Blake Hylton et al., 2020; Fleck \& Asmuth, 2020; a ahin et al., 2019); curriculum that bridges current conditions with what might happen in the future together with students who collaborate with different stakeholders (Nielsen \& Stovang, 2015) as well as a curriculum that adapts to local ties or local wisdom (Franco et al., 2010).

Apart from the relation to the curriculum, several demographic antecedents such as the family background of doing business, and the background of the student's business experience show different results. In business study program students, it did not show any relationship between the family background of doing business with entrepreneurial intentions, as well as the background of student business experience with entrepreneurial intentions. These results are different from those found in non-business study programs, where there is a relationship from weak to moderate between family backgrounds who do business with entrepreneurial intentions, as well as students' business experience background with entrepreneurial intentions. This finding can be a consideration that in fact there are several things that strengthen the intention of non-business study program students to become entrepreneurs even though they do not get entrepreneurial learning through direct entrepreneurship education such as in business study programs. This becomes interesting to observe for future researchers.

\section{- REFERENCES}

Bazan, C., Shaikh, A., Frederick, S., Amjad, A., Yap, S., Finn, C., \& Rayner, J. (2019). Effect of memorial university's environment \& support system in shaping entrepreneurial intention of students. Journal of Entrepreneurship Education (Vol. 22).

Blake Hylton, J., Mikesell, D., Yoder, J.-D., \& LeBlanc, H. (2020). Working to Instill the Entrepreneurial Mindset Across the Curriculum. Entrepreneurship Education and Pedagogy, 3(1), 86-106.

Bridgstock, R. (2013). Not a dirty word: Arts entrepreneurship and higher education. Arts and Humanities in Higher Education, 12(2-3), 122-137.

Brown, A. (2018). Embedding research and enterprise into the curriculum adopting Student as Producer as a theoretical framework. Higher Education, Skills and Work-Based Learning, 8(1), 29-40.

Carr, J. C., \& Sequeira, J. M. (2007). Prior family business exposure as intergenerational influence and entrepreneurial intent: A Theory of Planned Behavior approach. Journal of Business Research, 60(10), 1090-1098.

Chlosta, S., Patzelt, H., Klein, S. B., \& Dormann, C. (2012). Parental role models and the 
decision to become self-employed: The moderating effect of personality. Small Business Economics, 38(1), 121-138.

Fleck, E., \& Asmuth, J. (2020). Building Capacity for Creativity: Rediscovering the Inner "Superhero" as a Mechanism for Developing a Creative Mindset for Entrepreneurial Problem-Solving. Entrepreneurship Education and Pedagogy, 251512742091250.

Franco, M., Haase, H., \& Lautenschläger, A. (2010). Students' entrepreneurial intentions: An inter-regional comparison. Education + Training, 52(4), 260-275.

Gieure, C., Benavides-Espinosa, M. del M., \& Roig-Dobón, S. (2019). Entrepreneurial intentions in an international university environment. International Journal of Entrepreneurial Behaviour and Research, 25(8), 1605-1620.

Gupta, V. K., Dutta, D. K., Guo, G., Javadian, G., Jiang, C., Osorio, A. E., \& Ozkazanc-Pan, B. (2016). Classics in entrepreneurship research: Enduring insights, future promises. New England Journal of Entrepreneurship, 19(1), 7-23.

Hägg, G., \& Kurczewska, A. (2019). Toward a Learning Philosophy Based on Experience in Entrepreneurship Education. Entrepreneurship Education and Pedagogy, 251512741984060.

Hair, J. F., Black, W. C., Babin, B. J., \& Anderson, R. E. (2014). Multivariate Data Analysis (Seventh Ed). England: Pearson.

Iwu, C. G., Opute, P. A., Nchu, R., Eresia-Eke, C., Tengeh, R. K., Jaiyeoba, O., \& Aliyu, O.A. (2019). Entrepreneurship education, curriculum and lecturer-competency as antecedents of student entrepreneurial intention. International Journal of Management Education, (March), 100295.
Kautonen, T., Luoto, S., \& Tornikoski, E. T. (2010). Influence of work history on entrepreneurial intentions in "prime age" and "third age": A preliminary study. International Small Business Journal, 28(6), 583-601.

Kourilsky, M. L., \& Walstad, W. B. (1998). Entrepreneurship and female youth: Knowledge, attitudes, gender differences, and educational practices. Journal of Business Venturing, 13(1), 77-88.

Lackéus, M. (2020). Comparing the impact of three different experiential approaches to entrepreneurship in education. International Journal of Entrepreneurial Behaviour and Research, 26(5), 937971.

Lavelle, B. A. (2019). Entrepreneurship Education's Impact on Entrepreneurial Intention Using the Theory of Planned Behavior: Evidence From Chinese Vocational College Students. Entrepreneurship Education and Pedagogy, 251512741986030.

Lindahl Thomassen, M., Williams Middleton, K., Breum Ramsgaard, M., Neergaard, H., \& Warren, L. (2019). Conceptualizing context in entrepreneurship education: a literature review. International Journal of Entrepreneurial Behaviour and Research.

Martins, I., \& Perez, J. P. (2020). Testing mediating effects of individual entrepreneurial orientation on the relation between close environmental factors and entrepreneurial intention. International Journal of Entrepreneurial Behaviour and Research, 26(4), 771-791.

Nabi, G., Linan, F., Fayolle, A., Krueger, N., \& Walmsley, A. (2017). The impact of entrepreneurship education in higher education. Academy of Management Learning \& Education, 16(2), 277-299. 
Nielsen, S. L., \& Stovang, P. (2015). DesUni: university entrepreneurship education through design thinking. Education + Training, 57(8/9), 977-991.

Paray, Z. A., \& Kumar, S. (2020). Does entrepreneurship education influence entrepreneurial intention among students in HEI's?: The role of age, gender and degree background. Journal of International Education in Business, 13(1), 55-72.

Pahin, F., Karadað, H., \& Tuncer, B. (2019). Big five personality traits, entrepreneurial selfefficacy and entrepreneurial intention: A configurational approach. International Journal of Entrepreneurial Behaviour and Research, 25(6), 1188-1211.

Sancho, M. P. L., Martín-Navarro, A., \& Antonio Rafael Ramos-Rodríguez. (2020). Will they end up doing what they like? the moderating role of the attitude towards entrepreneurship in the formation of entrepreneurial intentions. Studies in Higher Education, 45(2).

Sekaran, U., \& Bougie, R. (2016). Research Methods for Business: A Skill-Building Approach (7th ed.). United Kingdom: John Wiley \& Sons Ltd.

Shirokova, G, Osiyevskyy, O., \& Bogatyreva, K. (2016). Exploring the intention-behavior link in student entrepreneurship: Moderating effects of individual and environmental characteristics. European Management Journal, 34(4), 386-399.

Shneor, R., Smith, J. B., Smith, C. G., \& Michael Goedecke, J. F. (2020). The Differential Impact of Entrepreneurship Education on the Entrepreneurial Intentions of Segments of Students. Entrepreneurship Education and Pedagogy, 251512742093624. 